\title{
The Study on the Elusion Approach to "Chain Scission" in the Fresh Agricultural Product Cold-chain Logistics
}

\author{
Xiaoya Ma \\ Guangxi Teachers Education University \\ GTEU \\ Nanning, China \\ E-mail:33013353@qq.com
}

\author{
Derong Wang \\ Guangxi Teachers Education University \\ GTEU \\ Nanning, China \\ E-mail:642729017@qq.com
}

\begin{abstract}
To find the way to avoid chain scission in the cold chain logistics chain of fresh agricultural products, the paper provides the guidance for the Stakeholder of logistics fresh agricultural products. It uses the methods of literature research and field survey, takes cold chain logistics chain as the breakthrough point, through the three aspects of practical research of the cold chain logistics nodes, cold chain logistics value chain stakeholders and cold chain logistics operators, to find out the essence of the cold chain logistics chain of fresh agricultural products in China, which only cannot protect the food safety of the fresh agricultural products, but also provides policy support for the fresh agricultural products production enterprises, processing enterprises, cold chain logistics enterprises and local government, to promote the healthy development of China's cold chain logistics industry in a certain extent.
\end{abstract}

Keywords- fresh agricultural products; cold-chain logistics; chain scission; seamless interface of logistics; chain scission elusion

\section{INTRODUCTION}

To strengthen the construction of agricultural products cold-chain logistics is crucial to the income increase of agricultural producers and food safety, which is clearly pointed out in the Development plan of agricultural products cold-chain logistics released by National Development and Reform Commission in 2010 and Notice on issuing the mid-term and long-term planning of logistics development from 2014 to 2020.. However, according to the data from China cold-chain logistics development report, the loss ratio of our fresh agricultural products in logistics links is from $25 \%$ to $30 \%$, which is around 12 million tons of fruits and 0.13 billion tons of vegetables, and the amount of loss is 75 billion RMB[1], which is mainly caused by the "chain scission" in the coldchain logistics operation of fresh agricultural products. In practice, the cold chain logistics of fresh agricultural products emphasizes the low temperature in the whole course, and the product quality and quality safety will be affected if one line appears "chain scission". Therefore, by analyzing the meaning of "chain scission" in fresh agricultural product cold-chain logistics, based on the "chain scission" point of fresh agricultural product coldchain logistics, the paper summaries the cause of "chain scission" and puts forward the elusion approach to the "chain scission" with the purpose of fundamentally promoting the income increase of fresh agricultural product producers, guaranteeing the quality of fresh agricultural products, reducing the loss of fresh agricultural products in the circulation process, and achieving the high efficiency and effectiveness of fresh agricultural products cold chain logistics operation.

\section{ANALYZE THE MEANING OF "CHAIN SCISSION" IN THE FRESH AGRICULTURAL PRODUCTS COLD CHAIN LOGISTICS}

\section{A. Analyze the meaning of cold chain logistics}

From the national standard logistics terms, only the definition of cold chain is found. Cold chain is the logistics network that is to maintain the quality of fresh foods and frozen foods, and keep the foods in low temperature all along through special equipment in the process of production and consumption [2]. The question from the definition of cold chain is what is the meaning of cold chain logistics. Scholar Ding Junfa (2010)[3] believed that cold chain logistics is the special supply chain system of foods that are perishable and easy to deteriorate, in the whole process starting from purchase from producing area, through product processing, storage, transportation, distribution and sales until being consumed, the foods are kept in the low temperature environment.

According to the definition of national standard logistics terms, the meaning of cold chain includes logistics and logistics network, which is essentially the logistics network operated in the low temperature condition in the whole distribution process. From the definition of scholar Ding Junfa, the cold chain logistics and cold chain are different; the essence of cold chain logistics is special supply chain system. From the difference, meaning and essence of the two definition, the meaning of cold chain is not as extensive as cold chain logistics, but they all have respective emphases; cold chain is to achieve the construction of logistics network, and cold chain logistics emphasizes the construction from the perspective of supply-chain system.

\section{B. Analyze the meaning of fresh agricultural products cold chain logistics}

Agricultural products of cold chain logistics are the special supply chain system of the fresh agricultural products such as meat, poultry, aquatic products, 
vegetables, fruits and eggs that are kept in the low temperature condition all along from harvesting in producing area, products process, storage, transportation, distribution and retail, greatly ensuring the product quality and quality safety and reducing loss and prevent pollution. Fresh means not being cooked or produced, which are the general terms of primary commodity with necessary preservation and simple arrangement for shelves, and commodities such as bread and prepared food that are processed on site[4]. According to the definition of agricultural products cold chain logistics, agricultural products cold chain logistics contains fresh agricultural cold chain logistics, whose range is wider than fresh agricultural products cold chain logistics. The fresh agricultural products cold chain logistics highlights the "fresh".

According to the above analysis, the paper believes that fresh agricultural cold chain logistics is the special supplychain system, in which meat, poultry, eggs, aquatic products, vegetables and fruits are not cooked or prepared, and are kept in the low temperature condition all along, after harvesting in producing area, products process, storage, transportation, distribution and retail, which reduces loss and prevents pollution. The smooth and effective fresh agricultural products cold chain logistics process is shown in Fig.1.

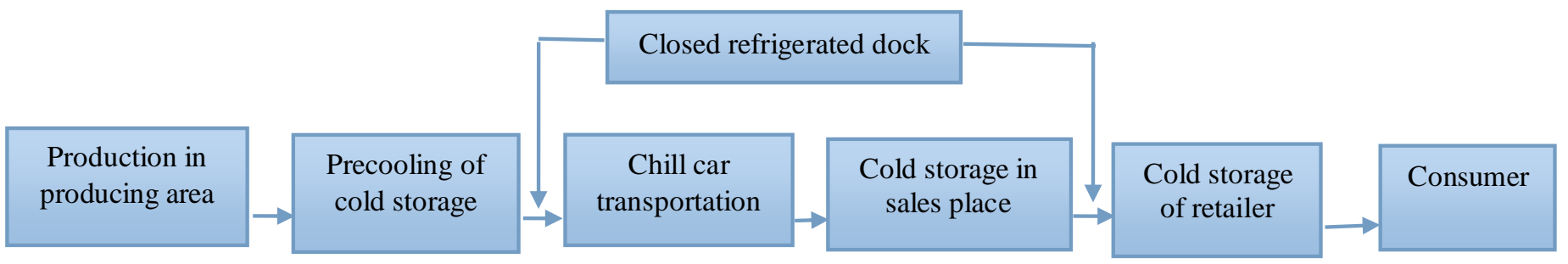

Figure 1. Smooth fresh agricultural products cold chain logistics

\section{The meaning of fresh agricultural products cold chain logistics "chain scission"}

In the current cold chain logistics research literature, "chain scission" concerning the cold chain logistics is first put forward by Liu Guangqi (2009) [5 ]in the paper named "where is the chain scission for cold chain and supply chain". Subsequently, Ding Junfa (2010)[3] spoke of the cold chain breaking point of cold chain and breakage of cold chain industry chain in the process of cold chain logistics in the paper which is named "value orientation of agricultural products logistics and cold chain logistics"; Duan Yali (2011)[6] analyzed the common shortcomings of "chain scission" in the process of cold chain logistics; countermeasures of "chain scission" in cold chain logistics. According to the document analysis and the meaning of fresh agricultural products cold chain logistics, the paper believes the chain scission of fresh agricultural products cold chain logistics is, in the process of fresh agricultural products cold chain logistics, the chain scission status in certain operational nodes or links when the fresh agricultural products are in normal or high temperature status due to the lack of cold chain logistics nodes, cold chain logistics equipment as well as not doing the job as required for the relevant enterprises and working personnel. The chain scission of fresh agricultural products cold chain logistics is shown in Fig.2. Lai Xiaozhen (2013)[7] explored the cause and
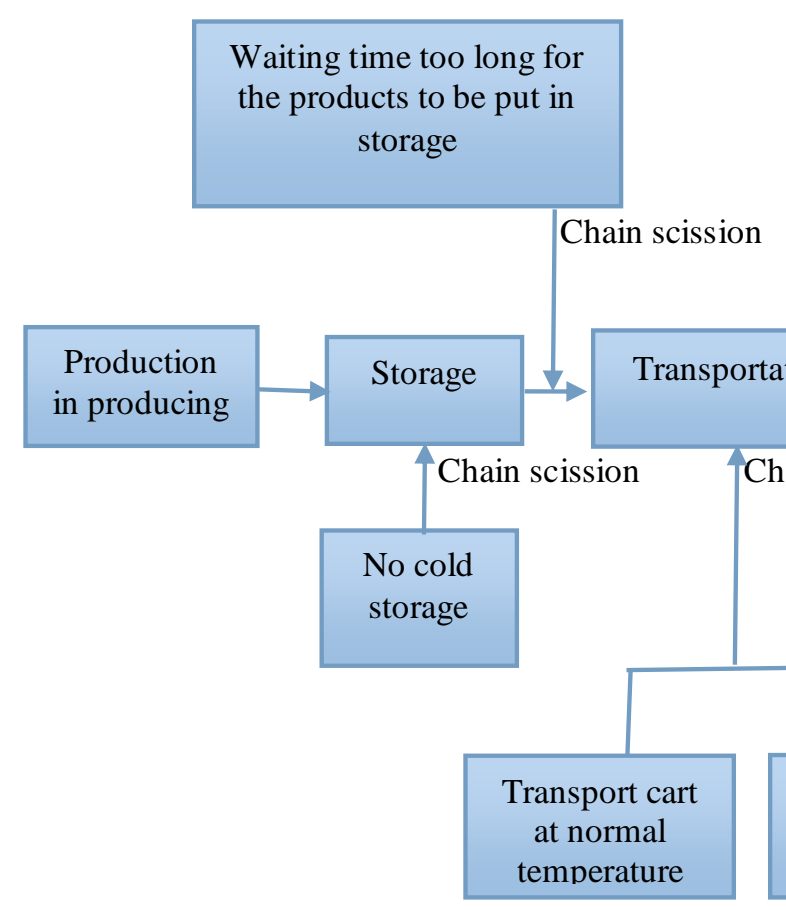

Figure 2.
Waiting time too long for the products to be put in storage

Chain scission

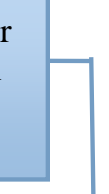

Chain scission 
III. ANALYZE THE CAUSE OF “CHAIN SCISSION” IN FRESH AGRICULTURAL PRODUCTS COLD CHAIN LOGISTICS

\section{A. Cold storage in short supply}

According to the data of the output of fruits and beet of main agricultural products in the <national statistics yearbook of 2010>, and the data in the <development planning for agricultural products cold chain logistics> issued by National Development and Reform Commission in 2010 , the comparison is shown in table 1 .

TABLE I. DATA OF FRUITS AND BEET OUTPUT AND TOTAL CAPACITY OF COLD STORAGE（UNIT:10,000 TONS）

\begin{tabular}{|c|c|c|c|}
\hline Name & Fruits & Beet & Cold storage \\
\hline output/storage capacity & 21401.4 & 929.6 & 880.0 \\
\hline Total & \multicolumn{2}{|c|}{22331.0} & 880.0 \\
\hline
\end{tabular}

Data source: National statistics yearbook of 2010, development planning for agricultural products cold chain logistics

According to Table 1, fresh agricultural products do not only include fruits and beet, but also include other vegetables, aquatic products, meat, etc. However, the output of fruits and beet is 0.22331 billion tons that is larger than the 8.8 million tons of the national cold storage capacity, which indicates the supply amount for cold storage is smaller than the demand, and the short supply is obvious.
B. Refrigerated lorry is not adopted in the process of fresh agricultural products transportation

\section{1) Insufficient refrigerated lorry}

According to the data of <development planning for agricultural products cold chain logistics in 2010>, there are 1,910 mechanically refrigerated trains, 20,000 mechanically refrigerated lorries, and refrigerated vessel with a tonnage of 100,000 . Compared with the data in national statistics yearbook of 2010, the number of refrigerated lorry is in significant lack. See the table 2 for more details.

TABLE II. ANALYZE THE PROPORTION OF REFRIGERATED LORRY AND CIRCULATION LORRY

\begin{tabular}{|c|c|c|}
\hline Name & Quantity & Proportion \\
\hline $\begin{array}{c}\text { Mechanically refrigerated train } \\
\text { (unit:PCS) }\end{array}$ & 1910 & $10.41 \%$ \\
\hline $\begin{array}{c}\text { Locomotive(unit:PCS) } \\
\begin{array}{c}\text { Mechanically refrigerated } \\
\text { lorry(unit:PCS) }\end{array}\end{array}$ & 18349 & $0.19 \%$ \\
\hline $\begin{array}{c}\text { Operated highway car(unit: } \\
\text { PCS) }\end{array}$ & 10501900 & \\
\hline $\begin{array}{c}\text { Refrigerated tonnage(unit: } \\
\text { 10,000-ton) }\end{array}$ & 10 & $0.06 \%$ \\
\hline $\begin{array}{c}\text { Civil transport ship(unit: } \\
\text { 10,000-ton) }\end{array}$ & 16898.5654 & \\
\hline
\end{tabular}

Data source: National statistics yearbook of 2010,development planning for agricultural products cold chain logistics

2) Operating companies aim to reduce the operating cost

Operating companies mentioned in this paper refer to the companies and individual household that participate in the process of fresh agricultural products cold chain logistics, including the third-party cold chain logistics enterprises, fresh agricultural products transport enterprises and transport individual household. According to the information disclosed in the year of 2012 by Shao Haitao, GM of Sinotrans Shanghai cold chain logistics CO., Ltd., and Huang Tianhua, Executive Assistant of China international Marine containers (Group) CO., LTD, the discrepancy of power consumption is $15 \%$ when the cold storage temperature is controlled at minus $25{ }^{\circ} \mathrm{C}$ and minus $18{ }^{\circ} \mathrm{C}$ in the aspect of cold storage temperature control; in the aspect of refrigerated truck, the standard cold storage transport cart accounts for less than $20 \%$ in the market; a lot of refrigerated truck is made out of obsolete shipping containers with the modification cost of $60,000 \mathrm{RMB}$, but the cost of minimum requirements for the standard refrigerated truck is more than 150,000 RMB.

According to the data analyzed by the cold chain logistics industry staff, the reason of "chain scission" in fresh agricultural products cold chain logistics is that enterprises try to reduce the operating cost.

3) Insufficient supervision and industrial standard not implemented

Despite of the cold-chain logistics classification and the basic requirements issued by General Administration of Quality Supervision and National Standards Commission in June $29^{\text {th }}$, 2012, which set clear legal norms to the cold chain logistics operation and basic requirements, which was known from the interview to Qin 
Yuming, Deputy Secretary-General of cold chain logistics professional board of China Federation of Logistics and Purchasing, in the current operation of fresh agricultural products cold chain logistic, at least in terms of highway transportation, relevant supervision departments only supervise the overload. However, whether the fresh agricultural products are transported with refrigerated trunk or controlled under certain temperature is unsupervised, which leads to relevant participants involved in fresh agricultural products operation ignoring the industrial standards.

\section{The waiting time for fresh agricultural products in and out of storage is too long}

1) The waiting time for fresh agricultural products to load truck from producing area cold storage is too long

When the precooled fresh agricultural products are loaded on the refrigerated trunks from the cold storage of producing area, in the process of outbound loading, the fresh agricultural products are exposed under normal or high temperature due to not closed low temperature platform in many cold storage. Meanwhile, because the general refrigerated truck trans-loading capacity is above the tonnage, and enterprises usually arrange about three people on the loading and unloading, in addition, most of the handling equipment are hand fork lifter, it takes some time to load the trunk. The fresh agricultural products, especially the frozen meat, will grow bacteria if exposed at normal temperature for more than 40 minutes, and the quality and presentation will be affected.

2) The waiting time of being put in storage is too long

$D$. The time of being put in storage here refers to the time which fresh agricultural products are being unloaded from transport vehicle to the cold storage of mall or supermarket. The causes of this problem are mainly: (1) warehouse operation arrangement of the enterprises receiving fresh agricultural products is not reasonable. According to the reports of Chinese Business Channel to Carrefour, the operation staffs for inbound loading are fewer compared with the vehicles that deliver goods to Carrefour, which leads to the waiting time of distribution staffs for inbound loading more than one hour. (2) The relevant distribution staffs are lack of cold-chain awareness and sense of responsibility. It is a gradual process for quality change of fresh agricultural products, and it takes a while for some fresh agricultural products to go bad. It is difficult to identify without instrument testing, and relevant distribution staffs and inbound staffs pay no attention. Under the current environment of logistics outsourcing for reducing enterprise production cost, the distribution personnel usually are the third-party distribution enterprises rather than the fresh agricultural products manufacturing enterprise. The outsourcing relationship makes the work focus of distribution staffs be to complete the distribution tasks, so they pay less attention to the consequences of quality change of fresh agricultural products when chain scission occurs in the distribution.

\section{E. Insufficient cognition to the cold chain logistics requirement}

Operation of fresh agricultural products cold chain logistics is accomplished by people, producers, operators and consumers are involved in the operation process. From Cold Chain Scission reported by Central Finance and Economics channel in September, 2012, and Neglect of Cold Chain reported in May, 2013, the cognition of cold chain logistics among producers, operators and consumers is insufficient. First of all, fresh agricultural products producers pay more attention to production and sales. From the perspective of producers, to keep the quality of fresh agricultural products by putting them into cold storage for pre-cooling and extending the sales time are meaningless. Second, because the logistics is in its infancy in our country; the professional cold chain logistics talents are in short, and the cognition of fresh agricultural products cold chain logistics for the working staffs are insufficient due to the lack of professional coldchain logistics training. In addition, consumers focus on the price of fresh agricultural products, and the quality change of fresh agricultural products which are the gradual process; consumers have cognition deficiency to the consequences caused by the chain scission of fresh agricultural products cold chain logistics, even pay no attention, and have no requirement to the adoption of cold chain logistics operation.

IV. ELUSION APPROACH TO THE “CHAIN SCISSION” OF FRESH AGRICULTURAL PRODUCTS COLD CHAIN LOGISTICS

\section{A. Strengthen the support from the macro-external environment}

1) Strengthen cold storage construction led by government and participated by enterprise

Domestic scholars hold two opposite views on the hardware facilities of cold chain logistics. Some scholars represented by Bao Changsheng $(2007)^{[8]}$ believed that the problem of development of cold chain logistics is the outdated management rather than the insufficient hardware facilities. Other scholars represented by Wang Ye(2013) ${ }^{[9]}$ and $\mathrm{Wu}$ Qinggang $(2011)^{[10]}$ believed that the infrastructure condition is poorer in the development of our fresh agricultural products cold chain logistics. From Table 1, the cold storage capacity of the fresh agricultural products cold chain logistics in China is far below the demand capacity. So in order to ensure the smooth implementation of fresh agricultural products cold chain logistics, on the cold chain logistics hardware facilities, the construction of cold storage should be strengthened in order to balance the supply with government as the leading force and through the form of financing and cooperation participated by the enterprises. Cold storage supply can ensure the demand, so fresh agricultural products manufacturers do not need to increase investment to establish cold storage, but to focus on the yield improvement of the fresh agricultural products. At the same time, in the era of globalization and informatization, management is a process that needs constant change. In the process, the basic support of cold chain logistics hardware facilities is necessary. Supported by the hardware infrastructure, manufacturers of fresh agricultural products will have stronger cognition to the 
cold chain, so they will store the products in the cold storage to extend the preservation time, seize the sale opportunity, and broaden sales channels, which provides conditions for the delayer sales strategy.

2) Strengthen supervision and strictly execute the cold chain industrial standard

At present, the national standards related to cold chain logistics are introduced, such as Working standard of low temperature storage, Management requirement of food cold chain logistics traceability, Cold chain management norms, etc. However, according to the actual investigation, even with the corresponding standard of cold chain logistics, because of the lack of supervision, some companies did not strictly enforce standards. Therefore, the government departments should strengthen supervision on enterprises to the strict enforcement of cold chain industrial standards. In concrete terms, it can be achieved by the following two aspects: (1) the administration for industry and commerce examines the existing cold chain logistics enterprises and private transportation enterprises, strictly supervises the enterprises involved in the cold chain logistics and transportation enterprises involved in the fresh agricultural products cold chain logistics, increases the working barrier by issuing operation certificate to the fresh agricultural products cold chain, obsoletes the individual households and small transportation enterprises who utilize normal temperature vehicles or covered with quilt with cotton wadding for heat preservation, and regulates the enterprises involved in fresh agricultural products cold chain. (2) increase the supervising function and scope of highway administration, not only the overload, but also the cold chain regulation involved with the green transportation vehicles with fresh agricultural products.

\section{B. Integrate the micro-environment, and enhance the} cognition of relevant people to cold chain logistics

1) Strengthen the coordination and integration of operating enterprises of cold chain logistics, and promote the development of third-party cold chain enterprise

The probability of chain scission and breaking point at the end of fresh agricultural products cold chain logistics is higher. For example, when the city distribution vehicles wait for the inbound loading of fresh agricultural products outside the malls or supermarkets, due to various types of goods, various suppliers, and different third-party logistics enterprises cooperated with each supplier, eventually the waiting time of the goods for inspection is too long. To shorten the time of "chain scission", from the current development situation of third-party logistics, one of the better ways for mall and supermarkets is to reduce the quantity of delivery enterprises and shorten the waiting time, which can reduce the amount of delivery enterprise requires resources integration of existing cold chain logistics enterprises, increase the coordination of the each cold chain logistics enterprises benefits, and promote the rapid development of third-party cold chain logistics enterprises.

2) Strengthen cognition of stakeholders to cold chain logistics

The stakeholders of the whole fresh agricultural products cold chain logistics include producers, circulation participants and consumers. Because the cold chain logistics is at primary stage, various stakeholders do not have enough cognition to the cold chain logistics and food safety. For example, cold storage pre-cooling is needed for the preservation of fresh agricultural products; the meat should be refrigerated and processed by acid return in order to promote the absorption of human. Due to the insufficient cognition of stakeholders to the professional common knowledge, lots of implicit wastes are caused. In order to save the storage charges of cold storage, the fresh agricultural products loss reaches to almost 50\%. In order to save the cost of car purchase, the fuel consumption increases $15 \%$. In order to buy the cheap fresh agricultural products, regardless of the health, people get ill due to eating bad agricultural products. From the point of longterm returns, the upfront input costs do more good than harm.

Thus, on the problem of "chain scission" in fresh agricultural products cold chain logistics, to enhance the cognition of stakeholders to the cold chain logistics can fundamentally solve the "chain scission", reduce the loss and implicit wastes. To enhance the cognition, the following three aspects can be done: (1) from central to local media, make periodic follow-up report to the development of fresh agricultural products cold chain logistics. Neglect of cold chain and Cold chain scission, made by Central Finance channel are good reports for the general knowledge. Central agricultural channels and local channels are all good channels for the general knowledge. (2) Government, enterprise and public institution should host more conferences related with cold chain logistics industry, which promotes the cognition of stakeholders to fresh agricultural products cold chain logistics. (3) the leading enterprises of fresh agricultural products cold chain logistics should lead to vigorously promote fresh agricultural products brand; through brand advertising, promotional materials and interpretation of relevant staffs, consumers will recognize the guarantee and promotion of cold chain logistics to the fresh agricultural products quality, which to a certain extent, promotes the healthy development of fresh agricultural products cold chain logistics.

\section{REFERENCES}

[1] Cold chain logistics specialized committee of China Federation of logistics and purchase, China Logistics Technology Association, Engineering and Technical Research Center of National Agricultural Products Modern Logistics. Reports to the China cold chain logistics development [R]. 2014:05.

[2] National Logistics Standardization Technology Committee and National Logistics Information Management Standardization Technology Committee. Logistics terms[S]. PRC National Standard: Logistics terms(GB/T 18354-2006).

[3] Jun Fa. Value orientation of agricultural products logistics and cold chain logistics[J]. China Business and Market. 2010(1): 26-28.

[4] National Development and Reform Commission. Development planning of agricultural products cold chain logistics[Z]. No. 1304, Development, Reform, Economy and Trade[2010]

[5] Liu Guangqi. Where is the chain scission of cold chain logistics[J]. China Storage\& Transport, 2009(04): 60-61.

[6] Duan Yali. The hurt of chain scission after chain scission "warming"[J]. Logistics Technology(Equipment Edition), 2011(4): 22-25.

[7] Lai Xiaozhen. Exploration on the reason of "chain scission" in cold chain logistics and solutions[J]. China Market, 2013(30): 1718 
[8] Bao Changsheng. Study on cold chain logistics operations management[D]. Shanghai: Tongji University, 2007.

[9] Wang Ye. Study on the development of fresh agricultural products cold chain logistics[J]. Journal of Chifeng College(natural science edition), 2013(1): 75-76.
[10] Wu Qinggang. Study on the status quo of cold chain logistics and solutions [J]. China Business and Market. 2011(02): 24-28. 